\title{
New Ways of Enhancing Classroom Experience
}

\author{
V.P Karthik \\ Assistant Professor in Pharmacology, Medical Education Unit, Sri Ramachandra Medical \\ College \& Research Institute \\ Corresponding Author : Dr. V.P Karthik \\ E-mail: dr_karthikvp@yahoo.co.in
}

\begin{abstract}
During the last couple of decades, the human generations have experienced a huge growth in the development of technology. In between the technological evolution, we have experienced two significant generations: Baby Boomers and Millennials which represents the huge change that the technology had and have on their behavior and lifestyle. The biggest challenge any teacher faces is capturing the students' attention and putting across ideas in such a way that it stays with them long after they have left the classroom. For this to happen, classroom experience should be redefined and innovative ideas that make teaching methods more effective should be implemented. So here are some innovative ways that will help teachers reinvent their teaching methods and enhance classroom experience: Game-Based Learning, Medical simulation, Social network, develop a class wiki/blog, create a podcast for your class, post shareable content, use a video chat system, Create classroom hashtags, Smart board etc. Around the country professional colleges are increasingly creating educational games for learners. Medical simulation is used in healthcare education to replace or amplify real patient experiences with scenarios designed to replicate real health outcomes, using life like mannequins, standardized patients etc. Edmodo is an online networking website made specifically to encourage post-class conversation between students and their teachers. Developing a class wiki/blog entice students to comment on lessons, topics and current events. With a classroom podcast, you can read passages from a textbook for discussions to take place on a certain topic that's in line with your curriculum. With Pinterest, you and your students can post photos of projects, activities, field trips and anything else that's class related. Moodle is a learning platform designed to provide educators, administrators and learners with a single robust, secure and integrated system to create personalized learning environments.
\end{abstract}

Key words: game-based learning, edmodo, moodle, pinterest, podcast

\section{INTRODUCTION}

During the last few decades, human generations have experienced a massive growth in the development of technology. In between the technological evolution, we have experienced two significant generations: Baby Boomers and Millennials which represents the huge change that the technology had and have on their behaviour and lifestyle [1].

\section{Baby boomers}

Baby Boomers are born between 1945 to 1965. Growing up with the development of technology, they are classified as digital immigrants. Boomers were in their teens to early 30 s when the first IBM PC's and Apples appeared. They grew up with technology, such as radio, television and landline telephones. Therefore, they did not have videogames or cell phones in their childhood. 
Table 1 - Overview of each generation

\begin{tabular}{|l|l|l|l|}
\hline & Baby Boomers & Generation X & Millennials \\
\hline Years of birth & $\begin{array}{l}\text { Late 1940s to early } \\
1960 s\end{array}$ & $\begin{array}{l}\text { Mid 1960s to late } \\
1970 \text { s }\end{array}$ & 1980 to 2000 \\
\hline $\begin{array}{l}\text { Relationship } \\
\text { technology }\end{array}$ & $\begin{array}{l}\text { Later members of this } \\
\text { generation were } \\
\text { exposed to new } \\
\text { media/technology } \\
\text { during formative }\end{array}$ & $\begin{array}{l}\text { First generation to be } \\
\text { raised on television }\end{array}$ & $\begin{array}{l}\text { First generation with } \\
\text { personal computers at } \\
\text { home }\end{array}$ \\
\hline $\begin{array}{l}\text { Reaction } \\
\text { technology }\end{array}$ & $\begin{array}{l}\text { Tries to understand } \\
\text { how new technology } \\
\text { works, marvels at it: } \\
\text { generally holds to } \\
\text { tradition, rather than } \\
\text { adopting new } \\
\text { technologies }\end{array}$ & $\begin{array}{l}\text { Tries to understand } \\
\text { how new technology } \\
\text { works, marvels at it: } \\
\text { generally adopts new } \\
\text { technologies easily }\end{array}$ & $\begin{array}{l}\text { Does not marvel at } \\
\text { technology. Adapts to } \\
\text { it. Uses it }\end{array}$ \\
\hline $\begin{array}{l}\text { Exposure to digital } \\
\text { media }\end{array}$ & $\begin{array}{l}\text { Individualistic } \\
\text { Experimental } \\
\text { Free-spirited } \\
\text { Social-cause oriental } \\
\text { Less optimistic } \\
\text { Distrusting } \\
\text { government } \\
\text { Cynical of }\end{array}$ & $\begin{array}{l}\text { Reactive } \\
\text { Realistic } \\
\text { Creative } \\
\text { Financially engaged } \\
\text { Work oriented } \\
\text { Independent } \\
\text { Rebellious attitudes }\end{array}$ & $\begin{array}{l}\text { 7+ hours/day } \\
\text { confident } \\
\text { Risk-taking } \\
\text { Optimistic }\end{array}$ \\
\hline
\end{tabular}

When it comes to technology, the Baby Boomers experienced a much different upbringing, compared to those born after them. The main technology breakthrough at that time was the rotary telephone and tube television. Otherwise, entertainment could be found outdoors with other children in the neighbourhood, where conversational skills, exercise and life lessons occurred [1]. So, when the Baby Boomers were first introduced to technology around 1960s, it had little impact on their everyday lives. Hence, technology did not play a pivotal role in that era. In the 1970s technology still had very little impact on the generation, because it was seen as something that only the academics used. During the 1980s, the technology slowly invaded people's homes and changed their behaviour. By means of technology, communication was improved to help customers make more informed decisions and to have better choices [2].

\section{Millennials}

Millennials are children of Baby Boomers and born between 1979 and early 2000's. Millennials are also known as the digital natives, because in their time, the technological evolution had reached an establishment [3].

Millennials have grown up in a time of rapid change, giving them a set of priorities and expectations sharply different from the Baby Boomers. Because in the 1990s, technology was now everywhere and it began to connect people around the globe. Around this century, the growth of technology became rapidly fast and explosive, but this was not a problem since the new generation was quickly adapting to it. Millennials have come of age during a time of technological change, globalization and economic disruption, which has given them a different set of behaviours and experiences than their parents. In the decade 2010, technology became fully integrated into people's daily lives. The internet and smartphones in an always-on digital world, has giving the Millennials a platform to reach the world [3].

Table 1: Overview of characteristics of each Generation 
Today, both Baby Boomers and Millennials have access to the same technology. However, the behaviour towards technology and its usage differs between the two generations [2].

Table 2: Overview of learning preferences of Each Generation

\begin{tabular}{|l|l|l|}
\hline \multicolumn{1}{|c|}{ Baby Boomers } & \multicolumn{1}{|c|}{ Generation X } & \multicolumn{1}{c|}{ Millennials } \\
\hline PowerPoint visuals & Modularized focused learning & Self-study downloads \\
Case studies & E-learning & Podcasts \\
Group discussion & Experimental learning & Webinars \\
Sharing of experiences & Active learning & Short sessions (1-4 hours) \\
& Sharing of best practices & Interactive group activities \\
& & Simulation \\
& & Game style presentation \\
& & \\
\hline
\end{tabular}

The biggest challenge any teacher faces is capturing the students' attention and putting across ideas in such a way that it stays with them long after they have left the classroom. For this to happen, classroom experience should be redefined and innovative ideas that make teaching methods more effective should be implemented. So here are some innovative ways that will help teachers reinvent their teaching methods and enhance classroom experience: Game-Based Learning, Medical simulation, Social network, develop a class wiki/blog, Create a podcast for your class, Post shareable content, Use a video chat system, Create classroom hashtags, Smart board etc. [2].

\section{Game Based Learning (GBL)}

Game based learning (GBL) is a type of game play that has defined learning outcomes. Generally, game based learning is designed to balance subject matter with gameplay and the ability of the player to retain and apply said subject matter to the real world. Game based learning describes an approach to teaching, where students explore relevant aspect of games in a learning context designed by teachers. Teachers and students collaborate in order to add depth and perspective to the experience of playing the game [4].

Good game-based learning applications can draw us into virtual environments that look and feel familiar and relevant. Within an effective game-based learning environment, we work toward a goal, choosing actions and experiencing the consequences of those actions along the way. We make mistakes in a risk-free setting, and through experimentation, we actively learn and practice the right way to do things. This keeps us highly engaged in practicing behaviours and thought processes that we can easily transfer from the simulated environment to real life [3].

Around the country professional colleges are increasingly creating educational games for learners. Pharmnexion, a game developed based on celebrity game show "Connection". Pharmzen, a game developed based on Snake \& Ladder. Pharmtris, modelled after the video game Tetris, helps medical trainees learn to recognize and treat diseases. Pharmstream, an online spaced education game teaches health care providers about different drugs. Kahoot! is a free game-based learning platform that makes it fun to learn - any subject, in any language, on any device, for all ages. www.educationarcade.org serves as resource for many educational games [4].

\section{Medical Simulation}

One of the most important steps in curriculum development is the introduction of simulationbased medical teaching and learning. Simulation is a generic term that refers to an artificial representation of a real world process to achieve educational goals through experiential learning. Simulation based medical education is defined as any educational activity that utilizes simulation aides to replicate clinical scenarios. Although medical simulation is relatively new, simulation has been used for a long time in other high risk professions such as aviation [5]. 
Medical simulation allows the acquisition of clinical skills through deliberate practice rather than an apprentice style of learning. Simulation tools serve as an alternative to real patients. A trainee can make mistakes and learn from them without the fear of harming the patient. No longer limited to "see one, do one, teach one, instead "see one, do many with simulation, teach one". There are different types and classification of simulators and their cost vary according to the degree of their resemblance to the reality, or 'fidelity'. Simulation- based learning is expensive. However, it is cost-effective if utilized properly. Medical simulation has been found to enhance clinical competence at the undergraduate and postgraduate levels. It has also been found to have many advantages that can improve patient safety and reduce health care costs through the improvement of the medical provider's competencies [5].

\section{Use of Social Networks}

Social networks provide various benefits to educational settings. Nevertheless, a dominant social network tool like Facebook is not suitable for classroom due to lacks of privacy concerns. Edmodo is a private social network that is claimed to provide a secure learning platform for learners and educators. Edmodo is an online networking website made specifically to encourage post-class conversation between students and their teachers [6].

The Edmodo network enables teachers to share content, distribute quizzes, assignments, and manage communication with students, colleagues, and parents. Edmodo is very teacher-centric in their design and philosophy: students and parents can only join Edmodo if invited to do so by a teacher. Teachers and students spend large amounts of time on the platform, both in and out of the classroom. It is a safe environment. There is no bullying or inappropriate content because the teacher can see everything that is posted on Edmodo [7].

\section{Blogs and Wikis in the Classroom}

Over the last few years, more and more educators have begun using blogs and wikis in the classroom. Developing a class wiki/blog entice students to comment on lessons, topics and current events. Students should also be allowed to create new posts about their thoughts. This is a great way to enhance creative writing [8].

\section{Blogs}

Blogs, short for "web logs" have become popular through all social circles. Blogs give an author or authors an opportunity to share information with large groups of people via the web in a very easy-to-use format. Readers of articles are able to post comments to them, which makes each blog a dynamic work-in-progress. Often used as a distribution point for information, news, and updates, many companies, newspapers, and individuals have experienced benefits from starting a blog [9]. In the classroom, blogs can be used as a place for students to talk about what they have learned, discuss perspectives on a news item, or provide information to individuals who have an interest in the class. There are multiple sources for free blogs. Edublogs and tumblr are few examples [9].

\section{Wikis}

Wikis are another dynamic tool for use in the classroom. Wiki means "quickly" in Hawaiian. Whether that is how they were named or if it is an acronym for "What I Know Is", using wikis is a way to create webpages without having any knowledge of the software programming languages required to write web pages. Wikis can be edited by several people, making them a useful tool for collaborative projects [10]. Wikis also give students an opportunity to reveal what they have learned, begin conversations about topics they are researching, and display projects or other products from the classroom. Wikis are very easy to edit. Usually it only takes clicking an "Edit" button and a user will be given the opportunity to add their own content in a what-you-see-is-whatyou-get (WYSIWYG) format. One example of a very popular wiki is Wikipedia [11].

\section{Create a Podcast for your class}

Technology isn't always about being seen; it can also be used to be heard. With a classroom podcast, you can read passages from a textbook for discussions to take place on a certain topic that's in line 
with your curriculum. This will teach broadcasting skills, speaking skills and critical thinking skills. You can also record the discussion, which can be reviewed by the class or future students. Many learning institutions are cutting back on textbooks and investing in technology enhanced learning. Podcasting, as one of the latest mediums to emerge into the mainstream, is one of the forefront technologies in this change [12].

Podcasting offers the opportunity for lecturers to easily broadcast engaging audio content, which students can then listen to at any time and wherever they are. Student only needs to subscribe to a podcast feed and suddenly you can push educational content to them, rather than wait for them to come. Podcasts can easily be used in Schools, universities or colleges to engage students, and improve your teaching and learning practise [13].

Many learning institutions which have incorporated podcasting in their education system, have reported really positive results. This can be attributed to the ease of creating and consuming podcasts as well as the various ways in which education podcasts enhance the students' learning experience.

There are a lot of advantages of podcasting in education. Let's take a look:

1. Flexible availability - 24 hours a day: One of the greatest advantages of education podcasts is the portability and convenience they offer. Podcasts can be downloaded to a mobile device, allowing the student to access the learning resources anytime, anywhere, with very little effort. There are podcast subscription apps available for nearly every smartphone, and these make the process even easier. Once the student has subscribed to a show, they don't have to initiate the download: it's sent automatically to their app whenever a new episode is available. So, as soon as they sit down on the bus, there's a teaching resource there waiting for them. This makes podcasts very convenient and also paves the way for truly flexible learning.

2. Students listen for longer than they watch or read: One of the great powers of podcasting is the attention it attracts. It's tricky to encourage students to spend 30 minutes reading an article or watching a recorded lecture. That's because text and video require the student's full attention - they need to sit patiently, doing just one thing. As you probably know, this is tricky, not least because of the range of distractions just sitting waiting on the next browser tab.

3. Podcasting, on the other hand, can be done in otherwise wasted time, or alongside a routine activity. Students are far more likely to listen to consume your material if they can do it on the bus, driving the car, washing the dishes or in the gym. Because they're already distracted with a rote task, the content gets great attention. While text and video struggle to attract 2 or 3 minutes of viewing, podcasts routinely run an hour or more.

4. Student created content: One of the most interesting and valuable uses of Podcasting in Education is the concept of student created content. You might allow students to create their own podcast, perhaps including questions, discussions, presentations or projects. These can then be made available to their classmates. This allows students to take control of an aspect of their education and, therefore, encourages engagement in the material. They can question, they can contribute and they can teach each other.

5. Lecture review: One of the simplest uses of Podcasting is to record your existing lectures. This makes them easily accessible for students and creates invaluable study aids. Students can use the podcast for reference purposes or when preparing themselves for upcoming examinations. Any student who had challenges understanding a topic in the classroom can listen to this podcast. The can study the content and understand the topic at their own pace.This capacity to review, again and again, is particularly valuable to students from an international background or with learning difficulties. Finally, as we mentioned earlier, it's a struggle to encourage students to watch a $1 \mathrm{hr}$ video recording of a lecture. Instead, give them audio and they can consume it while they do their chores.

6. Make up for missed classes: When a student misses a class, it's not always because they're lazy. By offering a podcast, your unlucky, sick student who has missed a number of classes 
can, instead, download recordings of the lectures. As a consequence, they're able to "fill in the gaps".

7. Moreover, a lecturer who is unable to attend his or her classes for a week or two can create a podcast of the lecture instead. This is made available to the students and thus makes up for any unattended lectures.

8. Consistency of student experience: Lecture recordings can help a teacher or professor to ensure that they always cover any given topic in the best way possible. This comes in handy when the lecturer in question teaches multiple sessions of the same class. It helps the teacher to ensure that every student gets the same experience, the same information, and that the syllabus is covered uniformly.

9. Benefits for mental and visual impairments: Perhaps one of the greatest pedagogic characteristics offered by educational podcasting is the chance to learn through listening. To many of the current student generation, learning through listening is enjoyable and less tedious than reading. Educational podcasts are appealing and may encourage students who don't like reading. Many students may struggle with reading through mental impairments, such as Dyslexia, and podcasts can be a big aid in this. Podcasts are equally useful in cases where a visual impairment makes traditional learning methods arduous [14].

\section{Post Class Activities on Pinterest}

Pinterest is a social network which allows you to share and comment on visual material, which could be photographs, sketches, videos or web pages. Like a virtual scrapbook, but very public, you can collate the items that you love. There is no copyright in the world of Pinterest: you can attach images from other people's web pages, or repin content from other people's boards. In fact, sharing content from other people is actively encouraged - this is about the social activity of interaction and sharing and gaining followers, rather than keeping ownership of your work. When the Pin It button is used to select pins from a web page, the pin automatically includes a link to the source web page, so you can remember where you found it, and other people can go to the source for more information [15]. With Pinterest, you and your students can post photos of projects, activities, field trips and anything else that's class related. Similarly, to YouTube, a private account can be created (no one but classroom students can log into the account). Since this is a visual medium, it will help to bring out creativity and confidence to share things with others [15].

\section{Post Shareable Content}

There's a more efficient way of sharing classroom notes, documents and projects and that's with programs like Google Docs, Moodle etc. Can also upload videos to a private channel just for your class using YouTube. Moodle is a learning platform designed to provide educators, administrators and learners with a single robust, secure and integrated system to create personalised learning environments. Moodle resources can be used for self-paced learning, remediation, assessment and many other educational strategies. Moodle facilitates flexible implementation, allows teachers to integrate a virtual learning environment at their own pace and opens the door to quick and easy sharing of educational resources. Opportunities for collaboration, dialog and discussion are also available in Moodle. Students find a variety of digital resources at one online location. Through a live connection, teachers who actively use Moodle will share their best practices [16-17].

\section{Use a Video Chat System}

The idea of pen pals can be enhanced using video chat systems like Skype, GoToWebinar etc. These systems can also be used to connect with experts or students from other classrooms that are far away. In this scenario, students will learn how to share experiences and build new relationships from a distance. Teleconferencing is a great way to teach children about teleconferencing etiquette, such as understanding when it's alright to connect and how to act when on camera. Skype in the classroom is a free community that connects teachers with educators and guest speakers from around the world. It is a website where teachers can find and run Skype lessons for their students. It enables teachers to find classes thousands of miles away or just round the corner, to collaborate 
and learn with. Skype in the classroom also helps teachers to connect to guest speakers who can offer their expertise during a Skype lesson with a class. It provides schools with the opportunity to easily invite zoo keepers, mountain climbers, professional athletes and authors into their classroom for a chat. All teachers that sign up to Skype in the classroom will also be given free group video calling to use in their classroom.

With Skype in the classroom you can:

1. Connect and collaborate with other educators using Skype

2. Find and engage with experts from a wide range of fields

3. Share and promote your own Skype lesson ideas and resources [18].

\section{Create Classroom Hashtags}

If you have a classroom of students, then most of them will likely have Twitter accounts. Why not make learning a bit more fun by having them contact popular personalities, or spread hashtags related to the topic of the day using Twitter? This could help gain interaction from people around the world who have something to share. By doing this, it can help teach your students the value of making connections and the influence it can have on them [19].

\section{Smart Boards}

Smart Board technology in the classroom can enrich curriculum by taking a typical lesson and turning it into a fun, more interactive one. It is an innovative learning tool which gives unlimited creativity in the hands of teacher. The SMART Board brings ideas, lessons and resources to life. Teacher uses interactive tools and designs higher level thinking activities that involve student collaboration, creativity and problem solving. SMART board maximizes the impact of the lessons by using a high quality interactive digital and multimedia content, keeps the track of past lessons and activities, involve enthusiastic participation from every student from anywhere in the class room, modify and customize interactive material to suit the teacher's approach and style of teaching, plan and share lessons collectively or access a huge wealth of teaching resources. Here are a few more of the amazing advantages to utilizing technology in the classroom by having a smart board in your classroom.

Advantages:

1. Smart Technology is Interactive: Perhaps one of the greatest advantages of Smart Boards is their ability to be interactive. Research has repeatedly demonstrated that students learn best when they are fully engaged, and hands-on learning is one of the best ways to do that. With this technology, every student in the classroom has the ability to utilize the Smart Board at the same time. For example, advanced Smart Boards have the ability for students to use their finger and write directly on them. Most Smart Boards have the separate workspaces so several children can utilize the smart board at once. This interactivity provides students the ability to write, draw, or take notes via a tablet as well.

2. They are Low Maintenance: Smart Boards are very easy to use and require very little maintenance. The boards do not use chalk or markers (which can be messy) -- you only use your finger or a special pen. You will also find that they very easy to clean as well as maintain.

3. You Have Access to Online Resources: Smart technology offers learners easy access to online resources. They can be set up in the class so all students can view any website or video through a computer application. Teachers have access to a slew of knowledgeable databases that which can help them reinforce their lessons. Students can easily access a wide range of resources to help them complete a project or conduct any research.

4. They are Environmentally Friendly: If you are looking to "Go green," then here is your chance. Smart Boards are environmentally friendly because it eliminates the need for any worksheets and papers. There will be no need to photocopy and print a class set of papers. These interactive boards will help the environment in eliminating the tons and tons of wasted paper and ink that are dumped each year.

5. Smart Boards Allow for Technology Integration: One of the many benefits of Smart Boards is the ability for technology integration. Teachers are able to attach their 
computers, video cameras, digital cameras, microscopes and pretty much anything else that you can think of to help aid in instruction.

6. Proven Success Rates: Studies have shown that using smart technology in the classroom has proven success rates; it raises test scores, improves student learning, enhances literacy, boosts attentiveness, and increases comprehension, to name a few.

7. Teachers report that the number one benefit that they see in their classrooms that use Smart Boards is an increase in student engagement. These interactive boards provide an extraordinary opportunity for teachers to create a classroom environment where students with different learning styles can learn from each other. This easy-to-learn technology ensures that both teachers and their students are developing the 21st century skills that they need in order to succeed in today's world [20].

\section{CONCLUSIONS}

In today's world, technology is a part of the daily lives of people all over the world. In order to keep civilization in sync with the technological advances, and to understand the connected future they will have, students in colleges, and other schools, have to be taught technical skills. Technology can be used as a way to learn, as well as a way to develop discipline. There is no concrete way to enhance classroom experience; each institution is advised to come up with its own way to suit the needs of their students. Since, it has been accepted globally that new ways should be in cooperated to enhance classroom experience and should not be left behind with traditional ways. We need to work towards the betterment of classroom experience after coming to consensus on what needs to be promoted and how to go about it. Therefore, the faculty and students should be involved not only in planning but also in deciding the strategy for implementation of new ways to enhance classroom experience. Undertaking the need assessment in every institution before planning a new way is crucial to address the specific needs. Involving a team of Medical education unit members, students and experts in ICT in this process would prove more beneficial.

\section{REFERENCES}

1. Myers KK, Sadaghiani K. Millennials in the Workplace: A Communication Perspective on Millennials' Organizational Relationships and Performance, J Buss Psychol 2010;25(2):225-38.

2. The evolution of technology across generations, November 10, 2016, Retrieved from http://edtechreview.in

3. Turner AR. Generation Z: technology and social interest. 2013.

4. Huotari K, Hamari J. Defining Gamification - A Service Marketing Perspective. October 3-5, 2012.

5. Abdulmohsen H. Simulation-based medical teaching and learning, J Fam Commun Med 2010;17(1):35-40.

6. Thongmak M. Social Network System in Classroom: Antecedents of Edmodo (C) Adoption. J e-Learning High Educ 2013;1:Article ID 657749,

7. Okumura S. The use of an educational social networking site for English language learning beyond the classroom in a Japanese university setting, Res Bull Education 2016;11:90-6.

8. Boulos MNK, Maramba I, Wheeler S. Wikis, blogs and podcasts: a new generation of Web-based tools for virtual collaborative clinical practice and education. BMC Med Educ 2006;6:41.

9. Warschauer M, Grimes D. Audience, authorship, and artifact: the emergent semiotics of web 2.0. Ann Rev Appl Linguistics 2007;27:1-23.

10. Choy S, Ng K. Implementing Wiki Software for Supplementing Online Learning. Australasian J Educ Technol 2007;23(2):209-26.

11. Rezvani E. Impact of Wiki-based Feedback on Grammatical Accuracy of Iranian EFL Learners' Writing Skill. Int J Foreign Lang Teach Res 2017;20(5). 
12. McGarr O. A review of podcasting in higher education:Its influence on the traditional lecture, Australasian J Educ Technol 2009;25(3):309-21.

13. Cheung TO. The effectiveness of educational podcasts for teaching music and visual arts in higher education, Res Learning Technol 2012;20:14919.

14. Dale K. Strategies for Using Podcasting to Support Student Learning, J Hospitality Leisure Sport Tour Educ 2007;6(1):49-57.

15. Duffy M. Microblogging: tumblr and pinterest, Am J Nurs 2013;113(6):61-4.

16. Cordero Torres JA, Caballero OA. The Moodle platform: A useful tool for training in life support. Analysis of satisfaction questionnaires from students and instructors of the semFYC advanced life support courses, Aten Primaria 2015;47(6):376-84.

17. Balakrishnan J, Griffiths MD. Social media addiction: What is the role of content in YouTube? J Behav Addict 2017;6(3):364-77.

18. McClure ER, Chentsova-Dutton YE, Holochwost SJ, Parrott WG, Barr R. Look At That! Video Chat and Joint Visual Attention Development Among Babies and Toddlers. Child Dev 2018;89(1):27-36.

19. Thomas A. Angelo K, Cross P. Classroom Assessment Techniques. 2nd Edition. JosseyBass: San Francisco, 1993.

20. Ikan EM, Dagan O. Using the Interactive White Board in Teaching and Learning - An Evaluation of the SMART CLASSROOM Pilot Project, Interdisciplinary Journal of ELearning and Learning Objects 2011;7(1).

Acknowledgements - Medical Education Unit, Sri Ramachandra Medical College \& Research Institute

Source of Funding - Nil

Conflict of Interest - Nil 